Prof. Th. Monod (U. de Paris): Notes sur quelques aspects du nomadisme pastoral en Afrique.

Dr. Jeremy Swift (U. of Sussex): Pastoral nomadism as a form of land-use: the Tuareg of the Adrar des Iforas.

M. Ch. Toupet (U. de Dakar): Le nomade, conservateur de la nature? L'exemple de la Mauritanie centrale.

Mme M. J. Tubiana (CNRS, Paris): Tradition et développement au Soudan Oriental : l'exemple Zaghawa.

Arrangements are being made for the publication of these papers, together with an introductory review by Professor Monod which will discuss the work of the seminar.

The Institute and the participants are grateful to the CNRSH and its Director, M. Dioulde Laya, and also to M. Boubou Hama, President of the Assemblée Nationale of the Niger Republic, for their generous assistance and warm hospitality on the occasion of the seminar. The close co-operation of Dr. Edmond Bernus with the Institute on behalf of the francophone participants in the preparation of the seminar programme was greatly appreciated. The Institute wishes again to express its thanks to the Ford Foundation for its supporting grant for the International African Seminars Programme which made this successful meeting, the last in the present series, possible.

\title{
Institute of African Studies, University of Ghana: Third Interdisciplinary Family
}

\section{Seminar}

A seminar on Aspects of Family Welfare and Planning, the third in a series of interdisciplinary family research seminars, was held in conjunction with the Home Science Department at the Institute of African Studies, Legon, from 9 to I I March 1973. Seventeen papers were presented by members of departments and institutes of the University of Ghana and of the Department of Social Welfare, Accra. The themes included family welfare and planning programmes; factors affecting family size and birth control; the care, health, and nutritional status of children in the several kinds of domestic and institutional settings; women's role in the home and at work; and the effects of conjugal family organization and breakdown upon members' welfare. An important theme which constantly received attention in the papers and discussions was that of the woman's role as mother, worker, and wife and the burdens imposed upon her by simultaneous childbearing and child-care and the task of earning a large part of the family living. Important questions were raised with regard both to future research and to the organization of relevant and adequate welfare programmes and services.

The fourth seminar, on Family Relationships and Resources in Ghana, is planned for the end of June 1973. The proceedings of these seminars are being published in the series Legon Family Research Papers, the first volume of which has been assisted by a generous grant from the Ford Foundation.

\section{University of Ghana: Seminar on the Brong Peoples}

AN interdisciplinary seminar on the Brong peoples of central Ghana was held at the Institute of African Studies, University of Ghana, Legon, from 16 to 18 March 1973 . Seeking to analyse the bases for distinguishing the Brong from the other Akan sub-groups, it discussed the following papers:

Prof. M. Posnansky: Archaeological aspects of the Brong Ahafo region.

Mr. E. K. Agorsa: The pre-history of the Begho area.

Dr. Kwame Arhin: Asante security posts in the north-west. 